\title{
Asupan Gizi dan Kadar Low Density Lipoprotein Kolesterol Darah pada Kalangan Eksekutif
}

\author{
Nutrient Intake and Plasma Low Density Lipoprotein Cholesterol among \\ Excecutive Group
}

Ratna Djuwita

Departemen Epidemiologi Fakultas Kesehatan Masyarakat Universitas Indonesia

\begin{abstract}
Abstrak
Kemajuan teknologi dan ekonomi akhir-akhir ini memberikan dampak perubahan pola hidup yang menyebabkan pergeseran pola penyakit. Terlihat pada peningkatan penyakit kardiovaskular pada kelompok eksekutif usia produktif. Hiperkolesterolemia adalah satu-satunya faktor risiko yang dapat menyebabkan timbulanya aterosklerosis. Asupan gizi terkait erat dengan hiperkolesterolemia. Tujuan penelitian ini adalah mengetahui hubungan antara asupan gizi serta pola makan dengan hiperkolesterolemia pada kalangan eksekutif di Jakarta. Desain penelitian adalah potong lintang. Populasi penelitian adalah kelompok eksekutif Indonesia dewasa berusia 25 - 60 tahun. Sampel penelitian terdiri dari 280 responden berusia 25 - 60 tahun yang merupakan kelompok eksekutif dari beberapa perusahaan yang ada di sekitar Jakarta. Kadar low density lipoprotein (LDL) kolesterol diperiksa dengan mengumpulkan sampel darah puasa. Asupan gizi dinilai dengan metode 24 hour recall dan pola makan dinilai dengan metode food frequency questionnaire (FFQ). Prevalensi hiperkolesterolemia pada kalangan eksekutif 46,1\%. Prevalensi hiperkolesterolemia ini lebih tinggi secara bermakna pada laki-laki $(50,9 \%)$ dibandingkan pada perempuan(29,7\%). Prevalensi hiperkolesterolemia cenderung lebih tinggi pada kalangan eksekutif yang berumur di atas 40 tahun, berpendidikan tinggi dan berpenghasilan tinggi. Asupan gizi, khususnya protein hewani serta frekuensi mengonsumsi sapi, memiliki hubungan dengan prevalensi hiperkolesterolemia. Asupan protein nabati, kekerapan mengonsumsi tempe, asupan serat serta kekerapan mengonsumsi sayur dan buah dapat dipertimbangkan sebagai makanan yang protektif atau dapat menurunkan kadar LDL kolesterol dalam darah.
\end{abstract}

Kata kunci: Asupan gizi, hiperkolesterolemia, kalangaan eksekutif

\section{Abstract}

Technology and economical development recently poses impact toward changes of lifestyle which cause shifted of the disease pattern. The escalating of cardiovascular appears to be more common among executive pro- ductive age group. Hypercholesterolemia is the only risk factor that by itself can cause atherosclerosis. Hypercholesterolemia might be influenced by nutrient intake. The objective of this study is to know the relationship of between nutrient intake as well as food pattern and hypercholesterolemia among executive group surrounding Jakarta. Low density lipoprotein (LDL) content was assessed by collecting fasting blood samples. 24 hour recall and food frequency questionnaire (FFQ) was conducted to assess nutrient intake. Prevalence hypercholesterolemia was $46.1 \%$ among this excecutive group.The prevalence of hypercholesterolemia was significant higher among men (50.6\%) compared to women (29.7\%).Hypercholesterolemia prevalence tend to be higher among those who were over 40 years old, had higher education and had higher income. There was a relationship between nutrient intake especially animal protein intake as well as more frequent consuming beef with the prevalence of hypercholesterolemia. Non-animal protein intake, more frequent consuming tempe, fibre intake as well as more frequent consuming fruit and vegetable might be considered as protective food toward lowering effect of the LDL plasma cholesterol level.

Keywords: Nutrient intake, hypercholesterolemia, excecutive group

\section{Pendahuluan}

Penyakit kardiovaskular merupakan penyebab kematian utama di seluruh dunia. Berdasarkan Riset Kesehatan Dasar (Riskesdas) 2007, penyakit kardiovaskular merupakan penyebab kematian utama di Indonesia. ${ }^{1}$ Faktor-faktor risiko penyakit kardiovaskular terbagi menjadi dua kategori yaitu faktor risiko yang dapat dikendalikan atau dimodifikasi dan faktor risiko yang tidak dapat dimodifikasi. Faktor risiko yang dapat dimodifikasi an-

Alamat Korespondensi: Ratna Djuwita, Departemen Epidemiologi FKM Universitas Indonesia, Kampus Baru UI Depok 16424, Hp. 0811927513, e-mail:drwita@yahoo.com 
tara lain hiperkolesterolemia, hipertensi, obesitas, diabetes melitus, kurang aktivitas fisik, dan merokok. Sedangkan, faktor risiko yang tidak dapat dikendalikan yaitu jenis kelamin, usia, dan faktor genetik. Penyakit kardiovaskular seperti serangan jantung dan stroke pembuluh darah otak umumnya disebabkan oleh terjadinya aterosklerosis atau penimbunan lemak pada pembuluh darah yang mengalirkan darah ke jantung dan otak. 2,3

Salah satu indikator aterosklerosis pada pembuluh darah adalah kadar kolesterol yang tinggi pada plasma darah yang kemudian disebut hiperkolesterolemia. Fraksi kolesterol plasma darah yang tergolong berkerapatan rendah untuk selanjutnya disebut low density lipoprotein (LDL) kolesterol atau sering disebut sebagai kolesterol "jahat". LDL adalah pengangkut lemak dari hati ke sel dalam tubuh. LDL memiliki sifat aterogenik, yaitu jika kadar LDL kolesterol darah tinggi dapat menyebabkan mudahnya penumpukan lemak, pembentukan plak pada dinding pembuluh darah. Kondisi tersebut dikenal sebagai aterosklerosis. ${ }^{4-6}$

Asupan gizi atau pola makan merupakan salah satu faktor risiko lingkungan utama dari penyakit kardiovaskular melalui kolesterol darah. Asupan gizi khususnya asupan asam lemak berkaitan erat dengan peningkataan kadar LDL kolesterol pada plasma darah. Asupan asam lemak jenuh yang umumnya berasal dari produk hewani jika dikonsumsi dalam jumlah banyak secara signifikan akan meningkatkan kadar LDL kolesterol darah maupun HDL kolesterol. Sedangkan, asupan asam lemak tidak jenuh sebagian besar berasal dari minyak yang berasal dari tumbuh-tumbuhan dan kacang-kacangan dapat menurunkan kadar LDL dan HDL kolesterol darah. ${ }^{7-9}$

Prevalensi penyakit kardiovaskular yang tinggi pada kelompok usia produktif diperkirakan berkaitan dengan prevalensi hiperkolestrolemia yang tinggi. Kelompok eksekutif usia produktif yang khususnya tinggal di kotakota metropolitan, seperti Jakarta dikategorikan sebagai kelompok populasi yang mempunyai pola hidup yang berisiko untuk menderita penyakit kardiovaskular pada usia yang relatif muda. Asupan gizi yang salah atau pola makan yang tidak seimbang merupakan salah satu pola hidup berisiko yang dapat dikendalikan. Tujuan penelitian ini adalah untuk mengetahui hubungan antara asupan gizi serta pola makan dengan hiperkolesterolemia pada kalangan eksekutif di Jakarta dan sekitarnya.

\section{Metode}

Penelitian ini menggunakan studi potong lintang. Populasi penelitian adalah orang yang berusia antara 25 - 60 tahun. Sampel responden dari penelitian ini adalah kelompok eksekutif dari beberapa perusahaan yang ada di sekitar Jakarta. Kelompok eksekutif adalah orangorang yang bekerja pada perusahaan tersebut dan berada pada tingkat manajerial. Jumlah responden pada peneli- tian ini adalah 280 responden. Prosedur pengambilan sampel dilaksanakan dengan metode multistage random sampling dengan perkiraan design effect 1,5. Pengambilan sampel darah puasa dilaksanakan untuk menentukan kadar LDL kolesterol darah responden dan dianalisis secara biokimiawi dilakukan di Laboratorium Fakultas Kedokteran Universitas Indonesia. Hiperkolesterolemia diidentifikasi jika kadar LDL kolesterol darah $\geq 130 \mathrm{mg} / \mathrm{dL}$ dan nonhiperkolesterolemia, atau biasa disebut normokolesterolemia, bila kadar LDL kolesterol $<130 \mathrm{mg} / \mathrm{dL}$. Pengumpulan data tentang asupan gizi dilakukan dengan metode one day 24-hour dietary recall dan dianalisis dengan menggunakan program khusus analisis nutrisi. Metode ini dilaksanakan untuk mengestimasi asupan gizi responden selama 24 jam terakhir, khususnya asupan energi, karbohidrat, total lemak, asam lemak jenuh, asam lemak tak jenuh, protein hewani, dan protein nabati. Metode food frequency questionnaire (FFQ) dilaksanakan untuk mengidentifikasi kekerapan responden mengonsumsi daging, sayur-sayuran, dan tempe. Wawancara dilaksanakan untuk mengumpulkan data sosiodemografi responden. Perbedaan proporsi variabel yang bersifat kategorik antara responden yang hiperkolesterolemia dan nonhiperkolesterolemia diuji dengan menggunakan kai kuadrat. Perbedaan rata-rata asupan gizi antara responden yang hiperkolesterolemia dan nonhiperkolesterolemia diuji dengan menggunakan uji $\mathrm{t}$ independen.

\section{Hasil}

Prevalensi kadar LDL kolesterol $\geq 130 \mathrm{mg} / \mathrm{dL}$, untuk selanjutnya dikategorikan sebagai hiperkolesterolemia pada kalangan eksekutif adalah 46,1\%. Prevalens hiperkolesterolemia pada laki-laki 50,9\% lebih tinggi secara bermakna dibandingkan dengan prevalensi pada wanita yaitu $29,7 \%$. Pada responden yang lebih tua ( $>40$ tahun) prevalens hiperkolesterolemia $(47,8 \%)$ lebih tinggi dibandingkan dengan responden yang lebih muda $(<40$ tahun) yaitu sekitar $41,6 \%$ dan pada responden yang pendidikannya prevalensi hiperkolesterolemia juga lebih tinggi $(49,5 \%)$ dibandingkan dengan responden yang pendidikannya lebih rendah $(43,8 \%)$. Sedangkan, prevalensi hiperkolesterolemia pada responden yang memiliki pendapatan $\geq 12$ juta rupiah lebih tinggi $(46,7 \%)$ dari responden yang pendapatannya $<12$ juta $(45,0 \%)$, meskipun demikian perbedaan-perbedaan prevalensi hiperkolesterolemia pada strata usia, pendidikan, dan pendapatan tersebut secara statistik tidak bermakna (Tabel 1).

Rata-rata asupan asam lemak jenuh pada laki-laki lebih tinggi (24,5 gram) daripada perempuan $(19,3$ gram) pada responden yang terdeteksi hiperkolesterolemia. Demikian pula pada responden yang nonhiperkolesterolemia (24,2 dan 21,3 gram), meskipun secara sta- 
Tabel 1. Karakteristik Sosiodemografi Berdasarkan Kadar LDL Kolesterol Darah

\begin{tabular}{lllllll}
\hline \multirow{2}{*}{ Karakteristik } & Kategori & \multicolumn{2}{c}{ Normokolesterolemia } & \multicolumn{2}{c}{ Hiperkolesterolemia } & \multirow{2}{*}{ Nilai $\mathbf{p}$} \\
\cline { 3 - 6 } & & $\mathbf{n}$ & $\%$ & $\mathbf{n}$ & $\%$ & \\
\hline \multirow{2}{*}{ Jenis kelamin } & Laki-laki & 106 & 49,1 & 110 & 50,9 & $<0,05$ \\
& Wanita & 45 & 70,3 & 19 & 29,7 & \\
\multirow{2}{*}{ Usia } & $\leq 40$ tahun & 45 & 58,4 & 32 & 41,6 & $>0,05$ \\
\multirow{2}{*}{ Pendidikan } & $>$ 40 tahun & 106 & 52,2 & 97 & 47,8 & \\
\multirow{2}{*}{ Pendapatan } & $>$ S2 & 95 & 56,2 & 74 & 43,8 & $>0,05$ \\
& $\geq$ S2 & 56 & 50,5 & 55 & 49,5 & \\
& $\leq 12$ juta & 61 & 55,0 & 50 & 45,0 & $>0,05$ \\
& $>$ 12 juta & 90 & 53,3 & 79 & 46,7 & \\
\hline
\end{tabular}

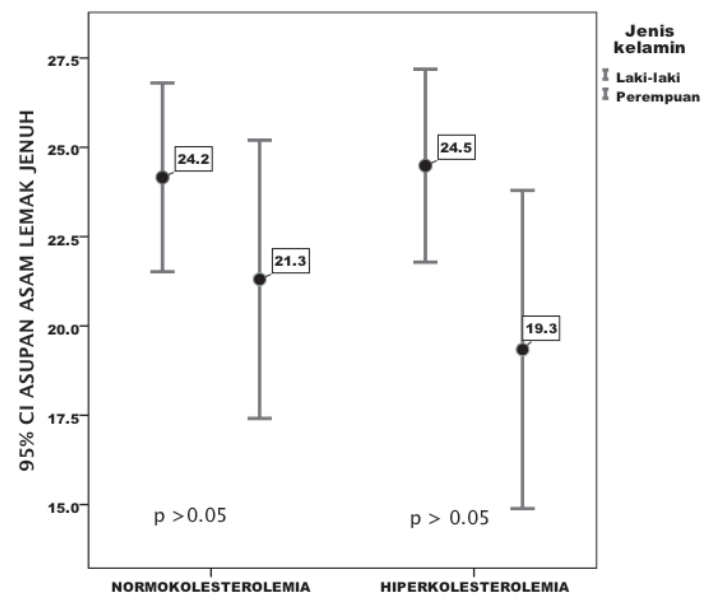

Gambar 1. Rata-rata Kadar Asupan Asam Lemak Jenuh Berdasarkan Hiperkolestrolemia dan Normokolesterolemia pada Laki-laki dan Perempuan

tistik perbedaan rata-rata ini tidak bermakna. Sedangkan, rata-rata asupan protein hewani pada laki-laki $(31,5$ gram) secara signifikan lebih tinggi dari pada asupan protein hewani pada perempuan (19,3 gram), baik pada responden yang hiperkolesterolemia maupun yang nonhiperkolesterolemia (28,5 dan 16,6 gram) (Gambar 1 dan Gambar 2).

Rata-rata asupan protein nabati pada laki-laki yang hiperkolesterolemia (28 gram) lebih rendah dibandingkan laki-laki yang nonhiperkolesterolmia (31,7 gram), begitu pula terlihat pada perempuan rata-rata asupan protein nabati lebih rendah pada responden yang hiperkolesterolemia (25,9 gram) dibandingkan dengan responden yang nonhiperkolesterolemia (30,9 gram). Pola yang sama terlihat pula pada konsumsi asupan serat, yaitu pada responden yang hiperkolesterolemia terlihat rata-rata asupan serat yang dikonsumsi lebih rendah dari pada responden yang tergolong nonhiperkolestrolemia (Gambar 3 dan Gambar 4). Namun, perbedaan rata-rata asupan protein nabati dan serat secara statistik tidak terlihat perbedaan yang bermakna. Daging sapi diidentifikasikan sebagai makanan sumber kaya asam lemak

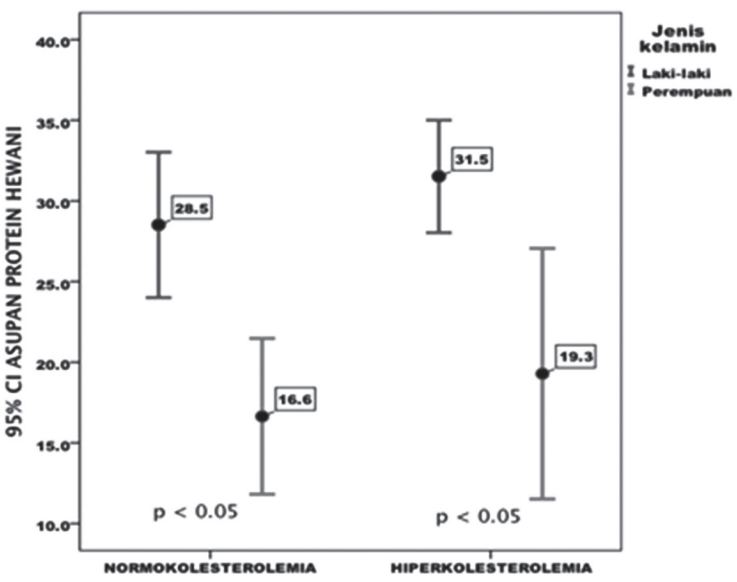

Gambar 2. Rata-rata Kadar Asupan Protein Hewani Berdasarkan Hiperkolestrolemia dan Normokolesterolemia pada Laki-laki dan Perempuan

jenuh dan protein hewani. Pada laki-laki yang sering mengonsumsi sapi, prevalensi hiperkolesterolemia (kadar LDL kolesterol $\geq 130 \mathrm{mg} / \mathrm{dL}$ ) adalah $54,1 \%$, sedangkan di antara responden yang jarang mengonsumsi sapi prevalensi hiperkolesterolemia (kadar LDL kolesterol $\geq$ $130 \mathrm{mg} / \mathrm{dL}$ ) lebih rendah yaitu $34,3 \%$. Pada perempuan yang sering mengonsumsi sapi, prevalensi hiperkolesterolemia adalah $43,3 \%$, sedangkan di antara responden yang jarang mengonsumsi sapi prevalensi hiperkolesterolemia lebih rendah yaitu $17,6 \%$. Perbedaan prevalensi baik pada laki-laki maupun perempuan secara statistik bermakna (Tabel 2).

Frekuensi mengonsumsi sayur dan buah dalam penelitian ini dianalisis berdasarkan hasil komposit dari berbagai macam sayur dan buah yang dikonsumsi oleh responden. Sayur dan buah diidentifikasikan sebagai sumber makanan kaya serat dan antioksidan. Prevalensi hiperkolesterolemia pada laki-laki yang jarang mengonsumsi sayur 56\%, nilai ini lebih tinggi dari responden yang sering mengonsumsi sayur dengan prevalensi hiperkolesterolemia, yaitu sebesar $45 \%$. Pola yang sama terlihat pula pada responden perempuan, yaitu pada kaum 


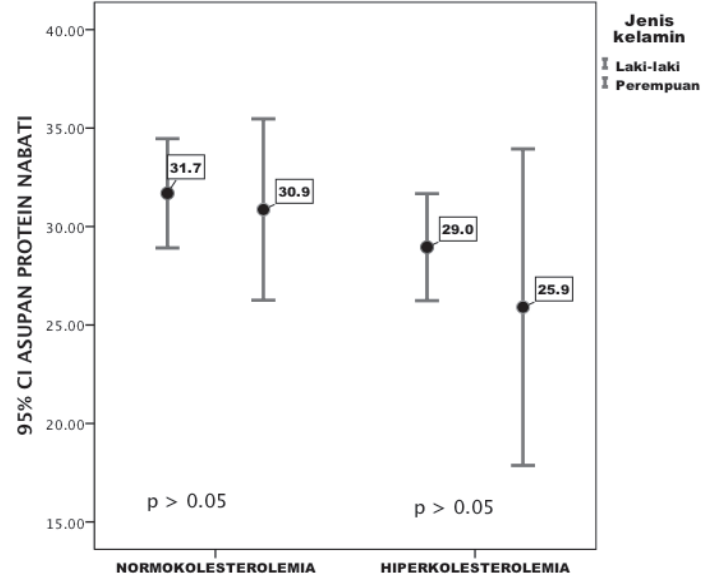

Gambar 3. Rata-rata Kadar Asupan Protein Nabati Berdasarkan Hiperkolestrolemia dan Normokolesterolemia pada Laki-laki dan Perempuan

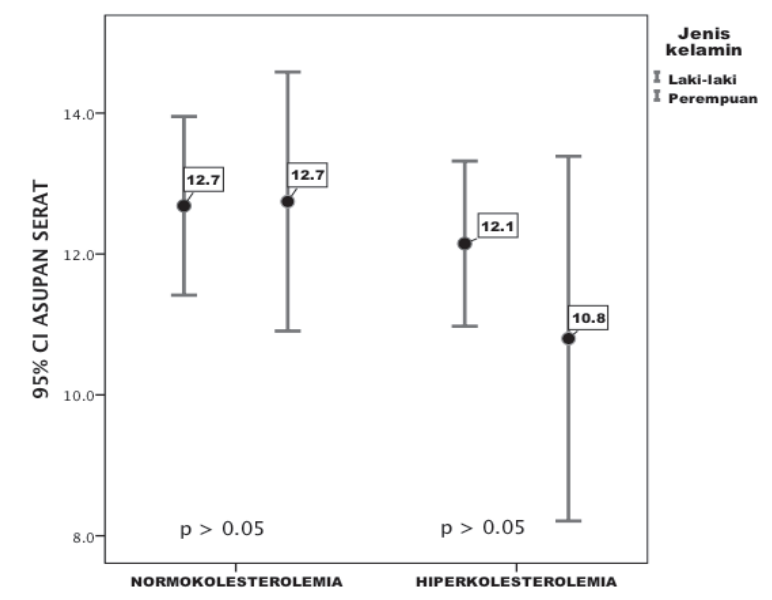

Gambar 4. Rata-rata Kadar Asupan Serat (Sayur dan Buah) Berdasarkan Hiperkolestrolemia dan Normokolesterolemia pada Laki-laki dan Perempuan

Tabel 2. Frekuensi Konsumsi Sapi, Sayur dan Buah, Serta Tempe Berdasarkan Hiperkolestrolemia dan Normokolestrolemia Antara Laki-laki dan Perempuan

\begin{tabular}{|c|c|c|c|c|c|c|c|}
\hline \multirow{2}{*}{ Jenis Makanan } & \multirow{2}{*}{ Jenis Kelamin } & \multirow{2}{*}{ Frekuensi } & \multicolumn{2}{|c|}{ Normokolesterolemia } & \multicolumn{2}{|c|}{ Hiperkolesterolemia } & \multirow{2}{*}{ Nilai $p$} \\
\hline & & & $\mathbf{n}$ & $\%$ & $\mathbf{n}$ & $\%$ & \\
\hline \multirow[t]{4}{*}{ Sapi } & \multirow[t]{2}{*}{ Laki-laki } & Jarang & 23 & 65,7 & 12 & 34,3 & \multirow[t]{2}{*}{$<0,05$} \\
\hline & & Sering & 83 & 45,9 & 98 & 54,1 & \\
\hline & \multirow[t]{2}{*}{ Perempuan } & Jarang & 28 & 82,4 & 6 & 17,6 & \multirow[t]{2}{*}{$<0,05$} \\
\hline & & Sering & 17 & 56,7 & 13 & 43,3 & \\
\hline \multirow[t]{4}{*}{ Sayur dan buah } & \multirow[t]{2}{*}{ Laki-laki } & Jarang & 51 & 44,0 & 65 & 56,0 & \multirow[t]{2}{*}{$>0,05$} \\
\hline & & Sering & 55 & 55,0 & 45 & 45,0 & \\
\hline & \multirow[t]{2}{*}{ Perempuan } & Jarang & 20 & 66,7 & 10 & 33,3 & \multirow[t]{2}{*}{$>0,05$} \\
\hline & & Sering & 25 & 73,5 & 9 & 26,5 & \\
\hline \multirow[t]{4}{*}{ Tempe } & \multirow[t]{2}{*}{ Laki-laki } & Jarang & 77 & 47.8 & 84 & 52,2 & \multirow[t]{2}{*}{$>0,05$} \\
\hline & & Sering & 29 & 52,7 & 26 & 47,3 & \\
\hline & \multirow[t]{2}{*}{ Perempuan } & Jarang & 26 & 68,4 & 12 & 31,6 & \multirow[t]{2}{*}{$>0,05$} \\
\hline & & Sering & 19 & 73,1 & 7 & 26,9 & \\
\hline
\end{tabular}

perempuan yang jarang mengonsumsi sayur dengan prevalensi hiperkolesterolemia 33,3\%. Nilai tersebut lebih tinggi dibandingkan responden yang sering mengonsumsi sayur dengan prevalensi hiperkolesterolemia pada kaum perempuan, yaitu hanya $26,5 \%$. Namun, perbedaan prevalensi hiperkolesterolemia dengan frekuensi mengonsumsi sayur dan buah pada responden laki-laki dan perempuan ini secara statistik tidak bermakna (Tabel 2).

Tempe diidentifikasi sebagai makanan kaya asam lemak tidak jenuh majemuk dan protein nabati. Pada responden laki-laki yang jarang mengonsumsi tempe, prevalensi hiperkolesterolemia adalah $52,2 \%$, sedangkan di antara responden yang sering mengonsumsi tempe prevalensi hiperkolesterolemia lebih rendah yaitu $47,3 \%$. Pada responden perempuan yang jarang mengonsumsi tempe, prevalensi hiperkolesterolemia adalah 31,6\%. Sedangkan, responden yang sering mengonsumsi tempe memiliki prevalensi hiperkolesterolemia lebih rendah, yaitu 26,9\%. Namun, perbedaan prevalensi ini secara statistik tidak bermakna (Tabel 2).

Pola variasi makan para responden dikelompokkan menjadi empat variasi pola makan, yaitu variasi pertama adalah jarang mengonsumsi daging sapi dan sayur tetapi sering mengonsumsi tempe, variasi kedua sering mengonsumsi daging sapi, sayur jarang tetapi sering mengonsumsi tempe, variasi ketiga sering mengonsumsi sayur dan tempe tetapi jarang mengonsumsi daging sapi, dan variasi keempat sering mengonsumsi ketiga kelompok makanan tersebut yaitu sering mengonsumsi daging sapi, sayur, dan tempe. Rata-rata kadar LDL kolesterol pada responden yang tergolong dari empat variasi mengonsumsi daging sapi, tempe, dan sayur, terlihat bahwa secara stastitik tidak ditemukan perbedaan yang bermakna. Terlihat kecenderungan pada responden yang sering mengonsumsi daging sapi, rata-rata kadar LDL kolesterolnya lebih tinggi $(129,1 \mathrm{mg} / \mathrm{dL}$ dan $116,8 \mathrm{mg} / \mathrm{dL})$ 


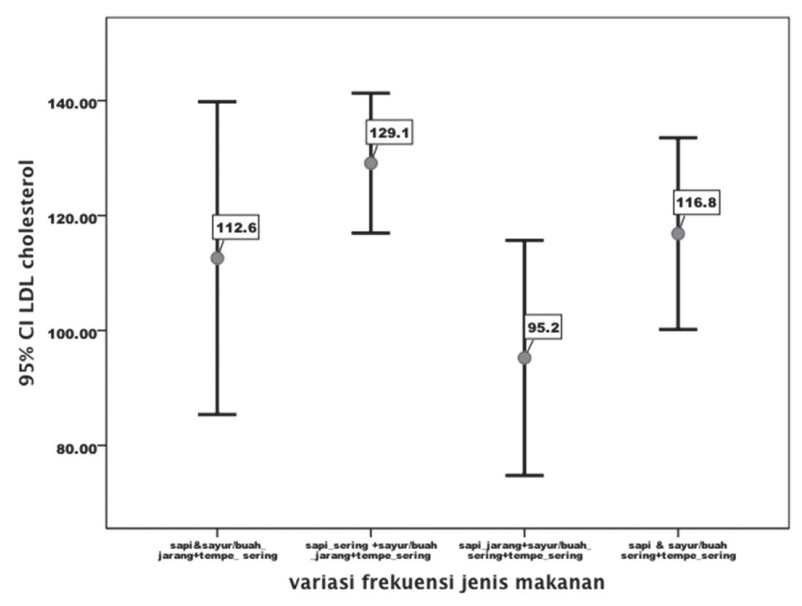

Gambar 5. Rata-rata Kadar LDL Kolesterol Berdasarkan Variasi Pola Makan Sapi, Tempe, Sayur dan Buah

dibandingkan responden yang jarang mengonsumsi daging sapi $(112,6 \mathrm{mg} / \mathrm{dL}$ dan 95,2 $\mathrm{mg} / \mathrm{dL})$. Lebih terlihat lagi kecenderungan bahwa pada responden yang jarang mengonsumsi daging sapi dan sayur tetapi sering mengonsumsi tempe rata-rata kadar kolesterol cukup rendah $112,6 \mathrm{mg} / \mathrm{dL}$, tetapi lebih rendah lagi terlihat pada responden yang jarang mengonsumsi daging sapi tapi juga disertai sering mengonsumsi sayur dan tempe, memiliki kadar kolesterol yang paling rendah 95,2 $\mathrm{mg} / \mathrm{dL}$ (Gambar 5).

\section{Pembahasan}

Penelitian ini merupakan penelitian potong lintang, dengan demikian tujuan penelitian ini hanya dapat untuk melihat hubungan antara asupan gizi dengan kadar LDL kolesterol, bukan merupakan hubungan sebab akibat. Karena desain studi ini tidak mempertimbangkan urutan waktu atau temporal relationship, asupan gizi dengan kadar LDL kolesterol dinilai pada penelitian ini pada waktu yang bersamaan. Peningkatan kadar LDL kolesterol dalam hal ini hiperkolesterolemia merupakan dampak kumulatif efek dari diet/asupan yang sudah berlangsung beberapa waktu sebelumnya. Bias pengukuran kadar LDL kolesterol telah diminimalkan dengan mengumpulkan darah puasa dari para responden dan darah dinilai di laboratorium yang dipercaya di Fakultas Kedokteran Universitas Indonesia. Kemungkinan bias dalam penilaian asupan gizi dikarenakan adanya recall bias dari responden dalam mengingat jenis dan jumlah makanan yang dikonsumsi, bias dari pengamat/pewawancara dalam mengestimasi/mengonversi berapa banyak makanan yang dikonsumsi diminimalkan dengan digunakannya food model serta bias dalam menghitung komposisi zat gizi dari jenis makanan yang mungkin tidak terdapat pada daftar Daftar Komposisi Bahan Makanan (DKBM).
Pada penelitian ini prevalensi hiperkolesterolemia dikategorikan sebagai hiperkolesterolemia bila kadar LDL kolesterol $\geq 130 \mathrm{mg} / \mathrm{dL}$. Berdasarkan kriteria $\mathrm{Na}$ tional Cholesterol Education Program - Adult Treatment Panel III (NCEP-ATP III), batas ini merupakan borderline high untuk risiko terjadinya penyakit jantung koroner. Penurunan kadar LDL kolesterol merupakan strategi sasaran utama untuk penatalaksanaan hiperkolesterolemia. ${ }^{10}$ Prevalensi hiperkolestrolemia pada kalangan eksekutif cukup tinggi yaitu $46,1 \%$, dibandingkan populasi pada umumnya. Pada studi empat etnik, prevalensi hiperkolestrolemia berdasarkan kadar LDL kolesterol $\geq$ $130 \mathrm{mg} / \mathrm{dL}$ tertinggi pada suku etnik Minangkabau sebesar $28 \%$ dibandingkan dengan ke tiga etnik lainya yaitu Sunda, Jawa, dan Bugis. ${ }^{11}$ Laporan data Survei Kesehatan Rumah Tangga (SKRT) 2004, prevalensi hiperkolesterolemia berdasarkan kadar total kolesterol $>200$ $\mathrm{mg} / \mathrm{dL}$ pada kelompok usia 25 - 34 tahun sebear 9,3\% dan prevalens tersebut meningkat sesuai dengan bertambahnya usia, pada kelompok usia 55 - 64 tahun sebesar $15,5 \%$. Pada responden yang tinggal di perkotaan prevalensi hiperkolesterolemia lebih tinggi daripada responden yang tinggal di perdesaan $(13,2 \%$ dan $10,9 \%) .{ }^{12}$ Prevalensi hiperkolesterolemia sebesar $21,1 \%$ terlihat pula pada para pekerja di tujuh perusahaan industri Pulo Gadung. ${ }^{13}$

Kalangan eksekutif pada penelitian ini memiliki pola gaya hidup yang berbeda dengan populasi pada umumnya sehingga dikategorikan sebagai kelompok yang mempunyai risiko tinggi untuk penyakit kardiovaskular. Prevalensi hiperkolesterolemia laki-laki di antara kalangan eksekutif pada penelitian ini lebih tinggi daripada prevalensi pada kaum perempuan. Terlihat pula bahwa prevalensi hiperkolesterolemia cenderung lebih tinggi pada kalangan eksekutif yang berumur di atas 40 tahun, berpendidikan tinggi dan berpenghasilan tinggi. Usia dan jenis kelamin merupakan faktor risiko yang tak dapat dikendalikan. Namun, 80\% dari penyakit kardiovaskular khususnya penyakit jantung koroner disebabkan oleh faktor risiko yang dapat dikendalikan. Hiperkolesterolemia merupakan salah satu faktor risiko yang dapat dikendalikan.

Rekomendasi dari NCEP-ATP III, bahwa penatalaksanaan hiperkolesterolemia dimulai dahulu dengan terapi perubahan gaya hidup Therapeutic Lifestyle Changes (TLC). Terapi perubahan gaya hidup ini terdiri dari mengurangi asupan lemak jenuh $(<7 \%$ asupan lemak jenuh terhadap total kalori) dan asupan kolesterol $(<200 \mathrm{mg} /$ hari) meningkatkan asupan makanan untuk menurunkan kadar LDL kolesterol darah, seperti meningkatkan asupan serat (soluble fibre)(10 - $25 \mathrm{~g} /$ hari), meningkatkan asupan protein nabati dan asupan stanols yang berasal dari tumbuh-tumbuhan ( $2 \mathrm{~g} / \mathrm{hari})$ dan menurunkan berat badan serta meningkatkan aktivitas fisik. ${ }^{10}$ 
Prevalensi hiperkolesterolemia yang cukup tinggi pada kalangan eksekutif pada penelitian ini tentunya dapat dimulai dengan mengubah gaya hidup, khususnya dalam hal ini dimulai dengan perubahan pola makan. Dengan demikian, perlu diketahui hubungan asupan gizi/pola makan dengan prevelansi hiperkolesterolemia kalangan eksekutif pada penelitian ini. Asupan gizi, khususnya asupan asam lemak jenuh merupakan komponen gizi utama dalam makanan yang kemudian akan menentukan kadar LDL kolesterol darah. Studi eksperimental pada binatang, studi observasional, studi randomized controlled trial, serta studi metabolik, secara konsisten menunjukkan adanya asosiasi antara asupan asam lemak jenuh dengan kadar kolesterol dalam darah. Analisis dari studi metabolik menunjukkan bahwa setiap peningkatan $1 \%$ kalori dari asam lemak jenuh akan disertai dengan peningkatan kadar LDL kolesterol darah sebesar 2\%.4,6

Asupan asam lemak jenuh dalam penelitian ini dinilai dengan metode 24 hour recall, yang di klasifikasikan sebagai metode kuantitiatif dimana tujuan dari metode ini untuk mengetahui jumlah makanan yang dikonsumsi responden, untuk kemudian dihitung jumlah asupan asam lemak jenuh dari makanan tersebut sesuai dengan komposisi yang tertera pada DKBM. Penelitian ini tidak menunjukkan perbedaan bermakna pada rata-rata asupan asam lemak jenuh pada responden yang hiperkolesterolemia dan normokolesterolemia. Namun, terlihat pada penelitian ini rata-rata asupan protein hewani laki-laki yang hiperkolesterolemia lebih tinggi secara bermakna daripada wanita yang hiperkolesterolemia maupun yang normokolesterolemia.

Penilaian asupan gizi lainnya yang dilaksanakan pada penelitian ini adalah metode food frequency questionnaire (FFQ), diklasifikasikan sebagai metode kualitatif di mana tujuan dari metode ini adalah untuk menilai kebiasaan makan, dalam hal ini dinilai kekerapan kebiasaan mengonsumsi sapi sebagai makanan sumber kaya asam lemak jenuh dan protein hewani. Terlihat pada responden yang sering mengonsumsi daging sapi, prevalensi hiperkolesterolemia lebih tinggi secara bermakna dibandingkan responden yang jarang mengonsumsi daging sapi, perbedaan ini terlihat baik pada kaum laki-laki maupun kaum perempuan. FFQ merupakan metode penilaian diet yang banyak digunakan pada studi epidemiologi untuk melihat hubungan asosiasi diet dengan suatu outcome penyakit (diet disease relationship). ${ }^{14}$

Asupan protein nabati atau soy protein memiliki kemampuan untuk menurunkan kadar LDL kolesterol. Metaanalisa dari studi uji klinis, menunjukkan bahwa konsumsi soy protein secara signifikan menurunkan kadar LDL kolesterol sebesar 12.9\%. ${ }^{15}$ Dinyatakan bahwa kadar isoflavone atau phytoestrogen pada protein nabati mempunyai hipokolesterolemik efek. Tempe merupakan salah satu makanan sumber protein nabati yang umumnya dikonsumsi oleh masyarakat di Indonesia. Purwantyastuti, 16 dalam penelitiannya menunjukkan bahwa peningkatkan asupan tempe berhubungan dengan penurunan kadar LDL kolesterol. Utari, ${ }^{17}$ pada penelitiannya menunjukkan bahwa kandungan asam amino pada tempe mempunyai potensi memperbaiki kadar profil plasma lipid.

Pada penelitian ini, rata-rata asupan protein nabati cenderung lebih rendah pada responden yang hiperkolesterolemik. Jika ditinjau dari asupan tempe, terlihat kecenderungan bahwa kalangan eksekutif yang sering mengonsumsi tempe prevalensi hiperkolesterolemia lebih rendah dibandingkan dengan yang jarang mengonsumsi tempe.

Asupan serat termasuk salah satu komponen gizi yang dianjurkan untuk dikonsumsi karena dapat menurunkan kadar LDL kolesterol darah. Studi klinis memperlihatkan bahwa makanan yang kaya serat yang larut dalam air seperti oat brand serta kacang-kacangan dapat menurunkan kadar LDL kolesterol sampai 22\%. ${ }^{18}$ Serat dapat menurunkan kadar kolesterol karena serat yang mudah larut tersebut mempunyai kemampuan untuk mengikat asam empedu, asam empedu merupakan hasil akhir dari metabolisme koslesterol. ${ }^{4}$ Rata-rata asupan serat pada penelitian ini terlihat kecenderungan sangat rendah pada responden yang hiperkolesterolemia hanya sekitar 10,8 dan 12,1 gram hari. Laporan pada tahun 2001 dinyatakan rata-rata konsumsi serat orang Indonesia yang tinggal di perkotaan sekitar 9,9 gram, tidak jauh berbeda dengan rata-rata asupan serat responden. ${ }^{19}$

Sayur dan buah pada penelitian ini dikategorikan sebagai makanan kaya sumber serat. Terlihat kecenderungan bahwa pada responden yang sering mengonsumsi buah dan sayur prevalensi hiperkolesterolemia lebih rendah dibandingkan dengan responden yang jarang mengonsumsi sayur dan buah. Untuk mencapai asupan serat yang direkomendasikan oleh NCEP, yaitu $25 \mathrm{~g} / \mathrm{hari}$, dianjurkan untuk mengonsumsi sayur atau buah sebanyak lima atau lebih dari lima porsi sehari. ${ }^{10}$ Dua penelitian kohort Nurse Health Study dan Health Professionals Follow up Study, ${ }^{20}$ menunjukkan terjadi penurunan risiko kardiovaskular sebesar $28 \%$ pada responden yang mengonsumsi lima porsi sayur dan buah-buahan per hari. Hasil Riskesdas 2007 menunjukkan bahwa 93,6\% dari penduduk Indonesia di atas 10 tahun mengonsumsi sayur dan buah $<5$ porsi per hari. ${ }^{1}$ Dengan demikian dapat dinyatakan secara umum pola makan penduduk Indonesia sehubungan dengan asupan serat masih rendah.

Dengan hanya membandingkan asupan gizi yang dapat meningkatkan dan menurunkan kadar LDL kolesterol kita tidak dapat menggambarkan pola makan yang sesungguhnya dari responden penelitian ini. Dengan menggunakan data dari FFQ kemudian dianalisa empat variasi dari pola makan kalangan eksekutif ini untuk kemudian 
dihubungkan dengan kadar LDL kolesterol. Terlihat kecenderungan bahwa dengan mengubah pola makan jarang mengonsumsi daging sapi tidak terlalu kuat untuk menurunkan kadar LDL kolesterol. Kadar LDL dapat menurun atau rendah sampai 95,2 g/dL, bila pola kekerapan makan diubah yaitu dengan jarang mengonsumsi daging sapi, tapi juga meningkatkan kekerapan mengonsumsi tempe, sayur, dan buah. Tempe, sayur, dan buah dapat dikategorikan sebagai makanan protektif terhadap hiperkolesterolemia.

\section{Kesimpulan}

Prevalensi hiperkolesterolemia pada kalangan eksekutif sebanyak 46,1\%. Prevalensi ini lebih tinggi pada laki-laki dibandingkan wanita. Asupan gizi khususnya protein hewani serta kekerapan mengonsumsi daging sapi ada hubungannya dengan prevalensi hiperkolesterolemia. Asupan protein nabati, kekerapan mengonsumsi tempe, serta asupan serat serta kekerapan mengonsumsi sayur dan buah dapat dipertimbangkan sebagai makanan yang protektif atau dapat menurunkan kadar LDL kolesterol dalam darah.

\section{Daftar Pustaka}

1. Departemen Kesehatan Republik Indonesia. Riset kesehatan dasar (Riskesdas) tahun 2007. Jakarta: Departemen Kesehatan Republik Indonesia; 2008

2. Steinberg D. Thematic review series: the pathogenesis of atherosclerosis: an interpretive history of the cholesterol controversy, part III: mechanistically defining the role of hyperlipidemia. J Lipid Res. 2005; 46: 2037-51.

3. Godfrey S. Getz, Catherine A. Reardon. Nutrition and cardiovascular disease. Arterioscler Thromb Vasc Bio. 2007; 27(12): 2499-506.

4. Krummel DA. Medical nutrition therapy for cardiovascular disease. Dalam : Mahan LK, Escott-stump S. Krause's Food and Nutrition therapy. Edisi ke 12. Canada: Saunders Elsevier; 2008.

5. Labarthe DR. Epidemiology and prevention of cardiovascular diseases, a global challenge. Jones and Bartlett Publishers, $2^{\text {nd }}$ edition, Sudbury Massachusetts; 2011.

6. Kuller LH. Nutrition, lipids, and cardiovascular disease. Nut Rev. 2006;
64(2): S15-26.

7. Lichtenstein AH, Appel LJ, Brands M, Carnethon M, Daniels S, Franch HA et al. Diet and lifestyle recommendations revision 2006: a scientific statement from the American Heart Association Nutrtion Committee. Circulation. 2006; 114: 82-96.

8. Micallef MA, Garg ML. The lipid-lowering effects of phytosterols and (n-3) polyunsaturated fatty acids are synergistic and complementary in hyperlipidemic men and women. J Nutr. 2008; 138: 1086-90.

9. Sabate J, Oda K, Ros E. Nutrition consumption and blood lipid levels a pooled analysis of 25 intervention trials. Arch Intern Med. 2010; 170(9): 821-7.

10. National Cholesterol Education Program (NCEP), Detection, Evaluation and Treatment of High Blood Cholesterol in Adults (Adult Treatment Panel III) Final Report; 2002.

11. Hatma RD, Lipid profiles among diverse ethnic groups in Indonesia. Acta Med Indones. 2011; 43(1): 4-11.

12. Soemantri S, Budiarso LR, Sandjaja. Survei kesehatan rumah tangga status kesehatan masyarakat Indonesia. Jakarta: Badan Penelitian dan Pengembangan Departemen Kesehatan Republik Indonesia; 2004.

13. Bantas K, Mutiarawaty F, Zakiyah TAD. Risiko Hiperkolesterolemia pada Pekerja di Kawasan Industri. Kesmas Jurnal Kesehatan Masyarakat Nasional. 2012; 6(5): 219-24.

14. Willet W. Food frequency method in nutritional epidemiology $3^{\text {rd }}$ edition. Oxford: Oxford University Press. 2013; 5: 70-95.

15. Zhan S, Ho SC. Meta-analyis of the effects of soy protein containing isoflavones on the lipid profile. Am J Clin Nutr. 2005; 81: 397-408.

16. Purwanttastuti. The relation of tempeh consumption and plasma lipid peroxides in the elderly. Majalah Kedokteran Indonesia. 2007; 57(10): 329-36.

17. Utari DM,Rimbawan,Riyadi H, Muhilal, Purwantyastuti. Potensi asam amino pada tempe untuk memperbaiki profil lipid dan diabetes Melitus. Kesmas Jurnal Kesehatan Masyarakat. 2011; 3(4): 166-70.

18. Galisteo M, Duarte J, Zarzuelo A. Effects of dietary fibers on disturbances clustered in the metabolic syndrome. Journal of Nutritional Biochemistry. 2008; 19: 71-84.

19. Jahari AB. Epidemiologi konsumsi serat di Indonesia gizi Indonesia. Journal of the Indonesian Nutrition Association. Vol XXV; 2001.

20. Hung HC, Joshipura KJ, Jiang R,Hu FB,Hunter D, Smith-Warner SA, et al. Fruit and vegetable intake and risk of major of chronic disease. J Natl Cancer Inst. 2004; 96(21): 1577-84. 